\title{
Corela
}

Cognition, représentation, langage

16-1 | 2018

Vol. $16, \mathrm{n}^{\circ} 1$

\section{Yes/no and Wh-Questions in Ňjò-Kóo : A Unified Analysis}

Simeon Olaogun

\section{OpenEdition}

Journals

Édition électronique

URL : http://journals.openedition.org/corela/6333

DOI : $10.4000 /$ corela.6333

ISSN : $1638-573 \mathrm{X}$

Éditeur

Cercle linguistique du Centre et de I'Ouest - CerLICO

Référence électronique

Simeon Olaogun, «Yes/no and Wh-Questions in Njọ̀-Kóo : A Unified Analysis », Corela [En ligne], 16-1 | 2018, mis en ligne le 12 juillet 2018, consulté le 19 avril 2019. URL : http:// journals.openedition.org/corela/6333; DOI : 10.4000/corela.6333

Ce document a été généré automatiquement le 19 avril 2019

\section{(c) (i) (2)(2)}

Corela - cognition, représentation, langage est mis à disposition selon les termes de la licence Creative Commons Attribution - Pas d'Utilisation Commerciale - Partage dans les Mêmes Conditions 4.0 International. 


\title{
Yes/no and Wh-Questions in Ňjọ- Kóo ${ }^{1}$ : A Unified Analysis
}

\author{
Simeon Olaogun
}

\section{Introduction}

1 Before Nkemnji (1995), Rizzi (1997) and Aboh and Pfau (2011), the widely held position was that wh-questions are formed by the movement of the wh-phrase to the left of focus marker in the Spec, FocP within the clausal left periphery, while yes/no questions employ different strategies depending on the language in question. For instance, in English, the derivation of yes/no questions was said to require three different rules : Aux-NP-Subject inversion, affix-hopping rule, and do-support, while in Yòrúba, yes/no questions were assumed to have been derived by adjunction as suggested in Yusuf (1992) when he said:

...the derivation of the yes/no questions in other languages may not be this syntactically exciting. For instance, in Yoruba, it is enough to adjoin a question particle to a declarative sentence. No movement is involved. Neither is any morphophonemic rule employed. Adjoined particles are Njẹ́ and șé, and a few dialectal or archaic forms are question markers ( $\mathrm{Q}-\mathrm{M}$ ).

2 Similarly, Ilọ̀ì (2010) posits that a yes/no question clause in Igálà and Yorùbá is derived by merging a convergent IP with the question element which regularly occurs clausefinally in Igálà and clause initially and finally in Yoruba while, wh-question clauses are derived by moving wh-operators to the Spec, QstP (Question Phrase) where they are immediately followed by the focus marker ni.

3 However, Nkemnji (1995), Aboh and Pfau (2011) challenge this commonly held position, and propose that both yes/no questions and wh-questions are projected by the same functional head Inter ${ }^{\circ}$, and also that wh-words do not participate in typing wh-clause as interrogative. This paper then investigates the claim in Njọ̀-kóo, and presents some empirically and theoretically motivated pieces of compelling evidence that lend credence to the said position. 


\section{Theoretical Framework}

4 The work is carried out within the Minimalist Program (henceforth MP), see Chomsky $(1995,1998,2000$, and 2002). The minimalist framework employs very few basic structurebuilding syntactic operations. They are : select, merge, and agree.

5 Operation Merge and Agree: It is assumed in this work that the computational system that forms syntactic objects is now composed of operations merge and agree. This is because operation move is assumed to be a subpart of merge and that agree is responsible for feature movement.

6 Operation Select chooses relevant lexical items from the lexicon and puts them into the numeration for further computation. Numeration is a storehouse of lexical items chosen from the lexicon for building larger syntactic objects. The items in the numeration are subsequently combined by operation merge.

7 Merge is a binary operation which combines two elements $\mathrm{X}$ and $\mathrm{Y}$ to form a larger unit that takes its syntactic category from either $\mathrm{X}$ or $\mathrm{Y}$ (Collins, 2013). Operation merge is of two types, namely, external and internal merge. External merge takes care of the merger operations of two independent elements which originate from the numeration, while internal merge is concerned with two dependent elements that are already introduced into the derivation.

Agree and Move F-based systems are two approaches developed to explain the conditions/ requirements for movement of features in the MP. In this paper, the agree-based method is employed. Agree-based system, as opposed to move- $\mathrm{F}$ technology holds the assumption that only [+interpretable] features of the lexical elements are specified in the lexicon before they enter the derivation, while elements with [-interpretable] features acquire their features in the course of the derivation. Given the appropriate domain for features matching, agree assigns values to unvalued features so as to satisfy morphological requirements while, at the same time, deleting such [-interpretable] features for LF purposes. Agree is a syntactic operation holding between a probe and a goal where a matching relation exists. Chomsky (2000) opines that for $\boldsymbol{\beta}$ to move to $\dot{\boldsymbol{\alpha}}$, a probe-goal relation must hold between at least one feature of $\dot{\boldsymbol{\alpha}}$ and a corresponding feature of $\boldsymbol{\beta}$. A probe is the highest head in a derivation which searches for a matching goal in its ccommanding domain, while a goal represents a constituent which is attracted by a higher head which serves as a probe (Radford 2009 : $387 \& 400$ ).

\section{Yes/no and Wh-Questions Defined}

9 Questions in natural languages can be classified into a number of types. One typological division, for example, is between yes-no questions and wh-questions (Radford 1988 :462). Yes-no questions are so called because they require, among other appropriate responses ${ }^{2}$, 'yes' or 'no' answers, whereas wh-questions are those that do not require yes or no answer but question a constituent. Wh-questions are generally used to refer to questions that involve an "independent" (wh-) interrogative word such as ko (what ?), konè (who? ), kòfọ̀n (when ?), kòsin (where ?) as exemplified in (2a-d) which are the wh-interrogative counterparts of the simple declarative sentences in (1a-d). 
1. (a) Títí bo ùji

Títí drink water

'Titi drank water'

(b) Igbéềi uwan ju ọgẹ̀dè

the child eat plantain

'The child ate plantain'

(c) Igbẹèji uwan ju ògè̀dè úrá

the child eat plantain yesterday

'The child ate plantain yesterday'

(d) Adé da àju rí aja

Adé buy yam in market

'Ade bought yam in the market'

2. (a) ko Títí yè bọ?

What Titi Inter drink

'What did Titi drink?'

(b) Konẹ è̀ ju ò̀gèdè ?

Who INTER eat plantain

'Who ate plantain?'

(c) Kòfọ̀n igbẹèji uwan yè ju ògèdè̀ ?

when the child INTER eat plantain

'When did the child eat plantain'?

(d) Kòsin Adé yè ke da àju?

where Ade INTER ADV buy yam

'Where did Ade buy yam?'

(e) Kòdí Adé yè ke da àju?

how Ade INTER ADV buy yam

'How did Ade buy yam?'

11 As seen above, the sentences in both (1) and (2) involve transitive verbs. This does not, however, mean that intransitive verbs cannot participate in the wh-questions in the language. Consider the sentences in (3a-d) and (4a-d) below.

3. (a) Bolu yè

Bolu dance

'Bolu danced'

(b) Òjó wôn

Ojo laugh

'Ojo laughed'

(c) Olú sẹn

Olu sleep

'Olu slept'

(d) Joké pà

Joke vomit

'Joke vomited'

4. (a) Konẹ è yè ?

Who INTER dance

'Who danced ?'

(b) Konẹ è wọn ?

Who INTER laugh

'Who laughed?

(c) Konè è sẹn?

Who INTER sleep

'Who slept?'

(d) Konè è pà ?

Who INTER vomit 
'Who vomited?'

The example sentences in (4a-d) are the constituent question counterparts of the declarative sentences in (3a-d)

Yes/no questions are illustrated in (6a - f).

5. (a) Igbẹèji uwan ju ògèdè̀

the child eat plantain

'The child ate plantain'

(b) djó vè

djó go

'Ojo went'

(c) Títí bo ùji

Títí drink water

'Titi drank water'

(d) Olú wọ̀

Olú cry

'olú cried'

(e) Délé da àju

Délé buy yam

'Dele bought yam'

(f) Na ba bàbá

You greet bàbá

'You greeted daddy'

6. (a) Igbẹèji uwan yè ju ògèdè é ?

the child INTER eat plantain EHT ${ }^{4}$

'Did the child eat plantain?'

(b) Ojó yè vè é ?

Ojo INTER go EMPH

'Did Ojo go ?'

(c) Títí yè bo ùji î ?

Titi INTER drink water EMPH

'Did Titi drink water?'

(d) Olú yè wọ́ ?

Olu INTER cry

'Did Olu cry?'

(e) Olú yè da àju ú ?

Olu INTER buy yam EMPH

'Did Olu buy yam ?'

(f) Na yè ba bàbá ?

You INTER greet daddy

'Did you greet daddy?'

It is observed that both yes/no questions and wh-questions are marked morphologically by the same distinct question morpheme yè which follows the subject DP immediately. However, there is an extra high tone that surfaces in clause final position in yes/no questions which accompanies the question morpheme. The high tone is, however, not usually realized in cases where the utterances independently end in high tone words/ morphemes as shown in (7a-b) below 
7 (a) Ojó yè vá ?

Ojo INTER come

'Did Ojo come?'

(b) Ojó yè ké é ?

Ojo INTER do it

'Did Ojo do it?'

19 It is noticed that the occurrence of this $\mathrm{H}$ tone is syntactically conditioned. Generally, it shows up in yes/no questions as shown in (6) above and focus constructions to show emphasis whenever there is movement of a DP to the clausal left periphery. It is also apparent from these examples that questions do not show a difference in word order with their declarative counterparts.

The occurrence and non-occurrence of this clause final high tone is not limited to direct yes/no and wh-questions but also occurs in indirect yes/no and wh-questions as exemplified in (8a-f) and (9a-f).

8. (a) Mu bìrè pé ko Bólú yè ju

I ask that what Bolu INTER eat

'I asked what did Bolu eat'

(b) Mu bìrè pé konẹ è ju ògè̀dè

I ask that who INTER eat plantain

'I asked who ate plantain'

(c) Mu bìrè pé kòfun Bólú yè ju ọgè̀dè

I ask that when Bolu INTER eat plantain

'I asked when did Ade eat plantain'

(d) Mu bìrè pé konè è vá

I ask that who INTER come

'I asked who came'

(e) Mu bìrè pé kòsin Adé yè ke gwẹ ewó.

I ask that where Ade INTER ADV collect money

'I asked where did Ade collect the money'

(f) Mu bìrè pé kàwán uwan Șégun yè șí.

I ask that how many child Șégun INTER bear

'I asked how many children did Șégun give

birth to'

9. (a) Mu bìrè pé Ade yè ju ọ̀gèdè ẹ

I ask that Ade INTER eat plantain EMPH

'I asked did Ade eat plantain'

(b) Mu bìrè pé Bólú yè ju ú

I ask that Bolu INTER eat EMPH

'I asked did Bolu eat'

c) Mu bìrè pé Bólú yà á vọ́dí ura ${ }^{5}$

I ask that Bolu INTER FUT arrive yesterday+EMPH

'I asked did Bolu arrive yesterday'

(d) Mu birè pé ojó yè vè é.

I ask that Ojo INTER go EMPH

'I asked did Ojo go'

(e) Mu birè pé igbẹệji ò̀ran yè hù ú.

I ask that the bird INTER fly EMPH

'I asked did the bird fly'

(f) Mu bìrè pé Jokẹ yè pà á.

I ask that Joké INTER vomit EMPH

'I asked did Joke vomit. 


\section{Derivation of Yes/No Questions}

21 Adopting cartography approach, the paper proposes, following Rizzi (1997) and Aboh (2004) that interrogative force is a specification of the functional head in Inter ${ }^{\circ}$ encoding the feature [Interrogative] that projects between ForceP and FinP as given in (10).

10. Force...>Inter...>Topic...>Focus...>Finiteness.

Therefore, I will propose in this paper that a simple yes/no question is headed by the Intero head which is morphologically realized as yè. So, a yes/no question like (6c) repeated here as (11) is derived as sketched in (12).

11. Títí yè bọ ùji î

Titi INTER drink water EMPH

'Did Titi drink water?'

12.

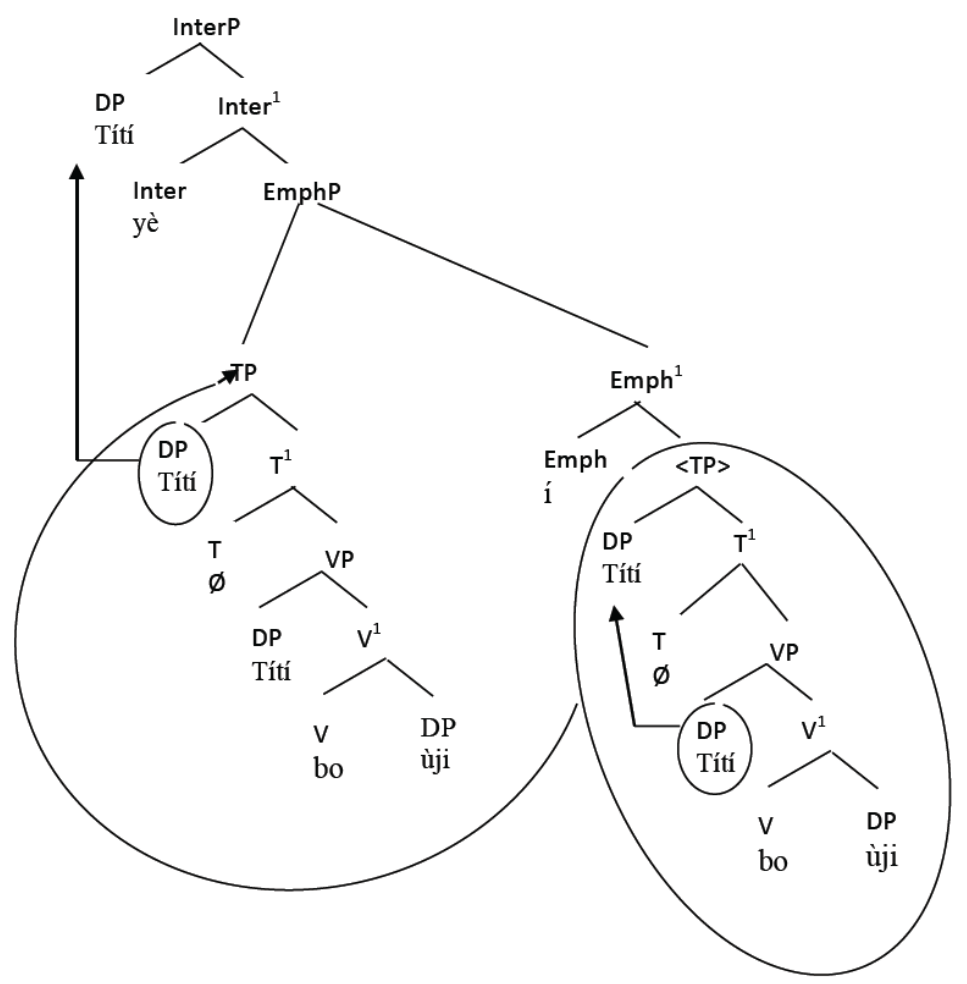

The syntax of yes/no questions involves two probes each of which can provoke displacement operations. The yes/no question in (12) is derived thus : The verb bo is first merged with its DP complement ùji (water) to satisfy the c-selection requirement of the head, while the subject DP Títí is second merged in the spec-VP (in line with the predicate internal subject hypothesis) in order to satisfy the EPP demand of the head. Then, $T$ head is merged with the VP to project T-bar. At this point, the T head becomes the probe which searches its c-command domain for a matching goal to attract to the spec-TP so as to value the unvalued/un-interpretable feature. The subject DP, Tití, being the potential and active goal with an unvalued nominative case, is attracted to the spec-TP and the unvalued case feature is valued and deleted.

The Emph head is externally merged with the TP to meet its c-selection condition. The whole TP pied-pipes to the spec-EmphP to also fulfill the EPP feature of the Emph head that is morphologically realized as the clause final high tone morpheme. 

EmphP to project Emph-bar. At this stage, the Inter head becomes the probe and begins to search its c-command domain for an active goal to move to its spec and value the unvalued feature. The only active goal is subject DP Títí because it is the only constituent that is licensed at the spec-InterP. The probe has [Inter-EPP] feature which is valued and deleted by moving the goal Títí to its specifier position. Put in another way, the probe yè has [Inter-EPP] feature which must be valued and deleted by moving the matching goal to its specifier position.

\section{A Unified Analysis for Yes/No and Wh-Questions}

The focus of this section is to propose a unified analysis for both yes/no and whquestions. The argument put forward above is that yes/no questions are headed by an interrogative morpheme Inter ${ }^{\circ}$ (which is morphologically realized as yè) that projects an InterP (Interrogative Phrase) and that the head of the InterP is licensed by the movement/raising of the subject of the finite clause to Spec, InterP. Given this assumption, the question that is begging for an urgent answer now is whether the analysis proposed for yes/no questions can be straightforwardly extended to whquestions. Definitely, I will also propose and defend the assumption that wh-questions have the same structure as yes/no questions. Precisely, I posit that wh-questions are also InterP headed by an Inter", and that the "feature" WH, in Nkemnji's words, is more like a scope marker that serves to delimit the constituent that is questioned.

\subsection{Analysis of Wh-Questions}

As said earlier, wh-questions and yes/no questions share a number of significant morphosyntactic properties. Just like yes/no questions, wh-questions involve a question particle yè (distinct from wh-phrase) that merges in Inter. For this reason, I argue that wh-questions are also headed by Inter ${ }^{\circ}$ head. Accordingly, I will analyze wh-questions in the same way as yes/no questions. As I intend to argue in the next section, the movement of wh-phrase is not meant to license interrogatives in wh-questions. Rather, the licensing of interrogatives takes place in overt syntax by way of the movement of the subject of the TP to the spec of InerP. Thus, a wh-interrogative like (13) is derived as sketched in (14).

13. Ko Títí yè ju

What Titi INTER eat

'What did Titi eat?' 


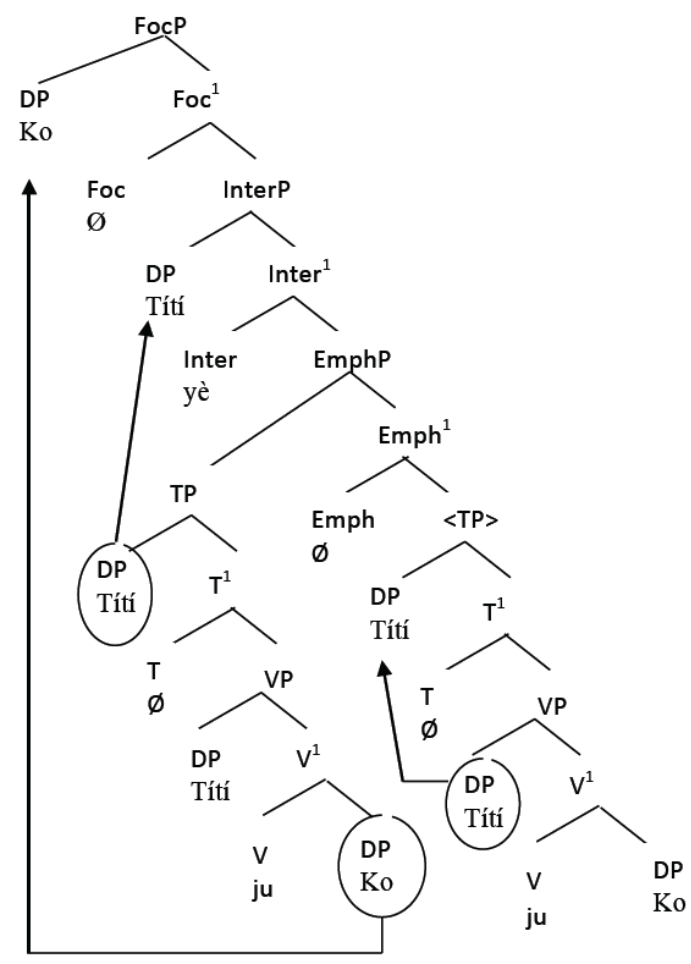

The syntax of a wh-question involves three probes, namely, inter, foc and emph, each of which has the potential to trigger displacement operations. The derivations go as follows : the verb ju 'to eat' merges with content word ko 'what' to satisfy its c-selection condition while the DP subject Títí is second merged in the spec-VP (in line with the VP Internal Subject Hypothesis) to satisfy the EPP demand of the head. Then $T$ head is merged with the VP to project T-bar. At this point, the T head becomes the probe which searches its c-command domain for a matching goal to attract to the spec-TP so as to value the unvalued/un-interpretable feature. The subject DP, Títí, being the potential and active goal with an unvalued nominative case is attracted to the spec-TP and the unvalued case feature is valued and deleted.

The Emph head is externally merged with the TP to meet its c-selection condition. The whole TP pied-pipes to the spec-EmphP to also fulfill the EPP feature of the Emph head that is morphologically realized as the clause final high tone morpheme.

There is a theoretical reason why the pied-piping of the TP to the spec-EmphP is necessary. Assuming phase impenetrability condition, if the probe yè is merged with the EmphP and later attracts the goal Titi to the spec-InterP, the phase domain of the Emph head will undergo transfer and will no longer be accessible for any syntactic operation. Therefore, this will block the movement of the content word to the spec, FocP and cause the derivation to crash. Similarly, if the ko-word is moved before pied-piping, it will also block the movement of the subject DP Tití to the spec-InterP, bringing about a nonconvergent derivation. This being the case, the whole TP is first pied-piped to the specEmphP, with other syntactic operations then following.

After pied-piping, yè is externally merged with the EmphP to project Inter-bar. The Inter head now becomes the probe which searches its c-commanding domain for a goal to raise to its spec. The subject DP, being the only active goal with [+Inter], then moves to the spec-InterP to value and delete the [Inter-EPP] feature of the probe head. 

The foc head now becomes the probe being the highest head which begins to search its ccommand domain for a matching goal. According to Chomsky, for a movement operation to take place, there must be an agreement relation between the probe and the goal. That is, the probe must have unvalued/un-interpretable feature while the corresponding feature must be valued or [+interpretable] on the goal so that, assuming feature valuation, the feature on the goal can be copied on to the probe. Given this, the probe has [focus-EPP] feature while the goal ko has [+foc] feature, the requirement for movement to take place is fulfilled. Therefore, the goal moves to the spec-FocP to value and delete the un-interpretable [foc-EPP] feature that is not legible at LF, which can cause the derivation not to converge at that interface level.

analysis in (14) is plausible in that, apart from the fact that the correct word order is realized, it also corroborates the unified analysis proposed in this paper. The analysis specifically assumes that Inter head yè merges with EmphP in both yes/no and whquestions.

The analysis also assumes that wh-questions involve the occurrence of the clause final high tone that occurs in yes/no and focus constructions as a mark of emphasis. This claim can also be theoretically justified. If we do not assume the existence of the clause final high tone for wh-questions, the unified analysis proposed for both yes/no questions and wh-questions would generate some questions. For instance, why is it that the inter head yè in yes/no question selects EmphP but the same yè performing the same function in wh-questions merges with TP ? But if we assume that a wh-question clause also has clause final high tone which is phonetically null, this asymmetry will disappear. Also, since we claim that yè licenses the existence of the clause final high tone morpheme in yes/ no question, and it also occurs in wh-questions, there is no way we can claim otherwise. The explanation one can offer is to say that it also occurs in wh-questions but phonetically null or not morphologically realized.

\subsection{Clausal Typing Hypothesis and Wh-Questions} whether a sentence is a question, declarative, relative, etc. is termed Clausal Type (Cheng, 1991), or the specification of Force (Chomsky, 1995). In her (1991:30) influential thesis titled "On the Typology of Wh-Questions", Cheng proposes Clausal Typing Hypothesis as follows :

Every clause needs to be typed. In the case of typing a wh-question, either a whparticle in $\mathrm{C}^{0}$ is used or else fronting of a wh-word to the Spec of $\mathrm{C}^{\circ}$ is used, thereby typing a clause through $\mathrm{C}^{\circ}$ by Spec-head agreement.

On this basis, Cheng categorizes all the languages of the world into two: Wh-in situ languages and Wh-movement languages. She claims that in Wh-in situ languages, whparticles are used to type a clause as interrogative, while in Wh-movement languages, wh-questions are typed by the movement of wh-word/phrase to the Spec, CP because such languages lack the kind of wh-particles (which she called typing particles) found in wh-in situ languages. In short, Cheng believes that the two syntactic phenomena are in complementary distribution. However, cross-linguistic evidence shows that there are whmovement languages with typing particles as demonstrated by the Igbo examples below. 
15a İ hừrù ònye?

You see-rV(past) who

'Who did you see?'

$\mathrm{b}$ Onye ${ }_{\mathrm{i}}$ kà î́ hựù $\mathrm{t}_{\mathrm{i}}$

Who that you see-rV(past)

'Who did you see?'

(Uwalaka, $1991: 186)$

Example (15a) instantiates a case where the wh-phrase remains in situ, while that of (15b) exemplifies an option where the wh-phrase is displaced to the sentence initial position.

\subsubsection{Typing Sentences as Interrogative}

There are two main proposals on how sentences are clause typed as interrogative in language, namely, (1) by using typing particles in wh-in situ languages or by using syntactic wh-movement in non-wh in situ languages (Cheng, 1991), and (2) by employing abstract syntactic X-bar category-InterP (Nkemji, 1995 and Aboh \& Pfau, 2011). Nkemji (1995) and Aboh \& Pfau (2011) opine that, cross-linguistically, sentences are typed as interrogatives by Inter head, contrary to Cheng's proposal.

41 Aboh and Pfau disagree with the assumption that wh-questions are derived by moving wh-phrase to the specifier of a focus projection cross-linguistically. They further claim that it is linguistically paradoxical to imagine that two functional heads with different properties (Inter, Foc) end up encoding the same discourse information (i.e interrogative force). This being so, they concluded that yes/no operators (or particles) and whoperators activate different articulations within the C-system, InterP and FocP, respectively. And that cross-linguistically, wh-phrases do not target the same position as evident in French. Therefore, wh-phrase does not participate in clause typing. It is just like a scope marker that serves to delimit the constituent that is questioned. Similarly, Ilori (2017) says that content word question operators are not interrogative heads but some kind of nominal words that interpret the focus of the interrogative force.

\subsubsection{Wh- questions and Clause Typing Evidence}

The paper argues in favour of the claim that sentences are clause typed as interrogative by InterP. This is because, in Njọ̀-Kóo, there is the presence of question particles as well as wh-movement, contrary to Cheng's claim that the two syntactic phenomena are in complementary distribution. Consider the sentences below.
16. (a) Títí bọ ùji
Titi drink water
'Titi drank water'
(b) Ko Títí yè bọ ?
what Titi INTER drink
'What did Titi drink?

Njộ-kóo is a wh-movement language because, when the DP object ùji in (16a) is questioned in (16b), the wh-word ko with which the object is questioned is preposed to the beginning of the wh-question clause as given in the tree diagram in (17).

17. 


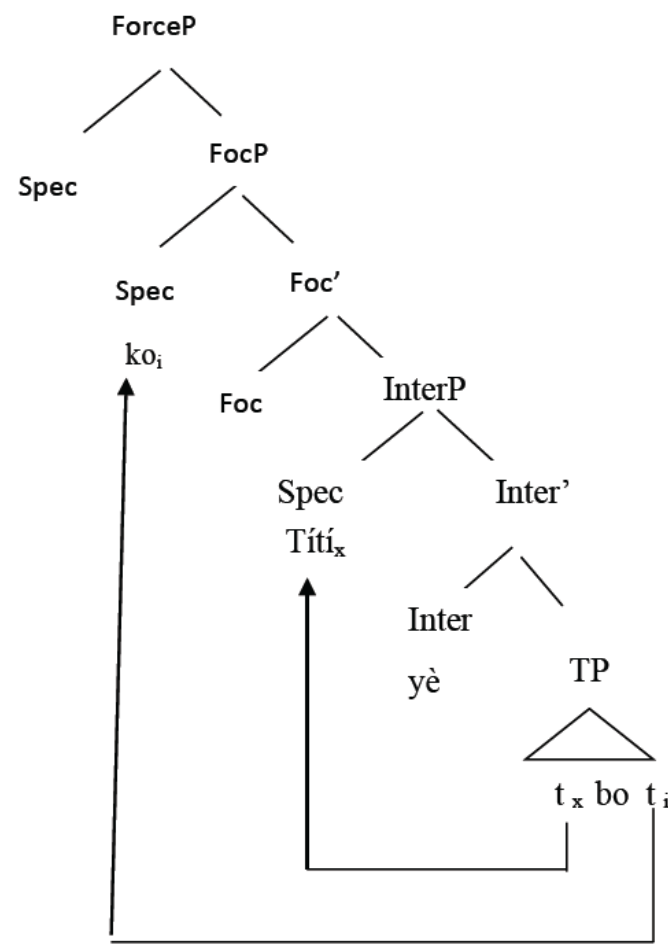

18 (a) Olú ju àju

Olu eat yam

Olu ate yam

(b) Ko Ø Olú yè ju?

What FOC Olu INTER eat

'What did olu eat?

(c) Àju úwọ̀n Olú ju ú

yam FOC Olu eat EMPH

' Olu eat YAM'. 
(18a) is a declarative statement ; (18b) is used to question the object DP in (18a), while (18c) is a response to the question. In the language, the focus marker is úwọn and its occurrence immediately after àju in (18c) indicates that àju is focused. Although the focus marker úwòn is phonetically null in wh-questions in Njò-kóo, the fact that the response to it in (18c) is a focused construction is an attestation to the fact that the question clause has got something to do with focusing. The conclusion therefore is that, because the wh-phrases are focused in Njọo-kóo, their answers must also be focus constructions. The preceding observation holds because not all languages permit this kind of syntactic operation. For instance, Aboh (2007) demonstrated the dichotomy between focused and non-focused wh-phrases/words. The answer to the non-focused whwords is never a focus construction as demonstrated in the Oromo data in (19), culled directly from Yiman $(1988: 370)$ :

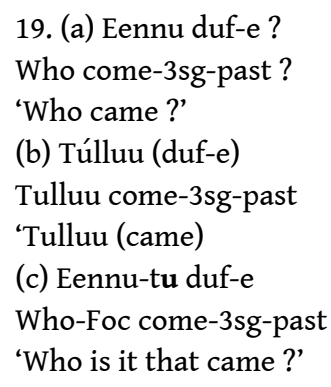

$\mathrm{Tu}$ is the focus marker in the language but its non-occurrence in the answer to the whquestion in (19a) is an attestation to the fact that wh-phrases may not be focused in the language.

Besides, there is empirical evidence indicating that wh-phrases in wh-questions or content word questions are not meant to clause-type expressions as interrogative. Thus, in English, there are expressions with wh-phrases that do not express interrogative force as exemplified in (20) taken from Aboh (2010) with modifications.
20. (a) We met the man whom you sanctioned last year.
(b) The committee decided over who will represent the University at the meeting
(c) The boy who bought a car last week is dead.

51 The fact that English wh-phrases occur in both declaratives and interrogatives as shown above further strengthens the argument that wh-phrases are not meant for typing clauses as interrogatives.

Furthermore, many wh-movement languages do not always have (overt) wh-phrases in wh-questions. For instance, according to Aboh (2010), Li and Thompson (1975) in their discussion of word order in Mandarin Chinese, report that Mandarin Chinese exhibits whquestions without wh-phrases as shown in the example below.

21. Yaoshi ne?

Key INTER

'What about the key(s) ?'

53 The example in (21) lacks wh-words but is interpreted as a wh-question. All that it contains is a noun phrase closely followed by a question particle : ne. Aboh reports that $\mathrm{Li}$ and Thompson (1981:305-306) claim that this declarative typing particle can also be employed to clause type various questions, including truncated questions that include only a noun phrase. What this suggests is that we can realize wh-questions in Mandarin Chinese without involving genuine wh-phrases such as shei (who?), sheme (what?), and duo (how ?), as shown in the examples below. 
22. (a) Hufei Chi-le sheme (ne) ?

Hufei eat Asp what QwH

'What did Hufei eat?'

(b) Shei mai-le sheme (ne)?

Who buy-Asp what QwH

'Who bought what?'

54 Similarly, Yoruba displays wh-questions without containing canonical wh-phrases such as kị (what ?), ta (who ?), mélòó (how many ?), as exemplified below.

23. (a) Fúnmi dà?

Funmi INTER

'Where is Funmi?'

(b) Bàtà yẹn ńkọ ?

shoe that INTER

'Where is that pair of shoes?'

(c) Victor ńkọ ?

Victor INTER

'Where is Victor?'

'How/What about Victor?'

As demonstrated above, the questions in $(23 a-c)$ which involve the use of question particles dà and ńkó lack wh-words but are all interpreted as wh-questions. This is another piece of evidence that supports the fact that wh-words do not express interrogative force. The genuine wh-words in Yoruba are kí (what), ta (who), mélòo (how many), as exemplified in the questions below.
24. (a) Kí ni Olú rà ?
What FOC Olu buy
'What did Olu buy?'
(b) Ta ní Olú rí
who FOC Olu see
'Who did Olu see?'

Finally, questions do have question particles, regardless of whether the language involves wh-phrases and/or wh-movement. For example, languages such as Lele and Njò̀-kóo, which are wh-movement languages, have question particles as well as wh-phrases in the same sentences as given in (25a-b) and (26a-e) respectively.
25 (a) Wey ba é gà ?
Who FOC go INTER
'Who went away'?
(b) Me ba gol dí gà ?
what Foc see 3sg INTER
'What did you see?'
(Aboh \& Pfau 2011)
26. (a) ko Títí yè bo ?
What Titi INTER drink
'What did Titi drink?'
(b) Konè̀ yè ju ọ̀gèdè ?
who INTER eat plantain
'Who ate plantain?'
(c) Kòfọ̀n igbếèji uwan yè ju ògè̀dè ?
when the child INTER eat plantain'
'When did the child eat plantain'?
(d) Kòsin Ade yè da àjú ?
where Ade INTER buy yam
'Where did Ade buy yam?' 
(e) Kòdí Adé yè da àju?

how Ade INTER buy yam

'How did Ade buy yam?'

57 The only plausible conclusion we can draw from this is that the particle is silent (i.e phonetically null) in English but overt in Mandarin Chinese, Ǹjọ-kóo, and Lele.

\section{Conclusion}

The thrust of this paper has been to provide a unified analysis for yes/no questions and wh-questions, and also to prove that the movement of wh-word in wh-question clause is not for clause typing but, rather, for interpretive purposes. As opposed to Cheng (1991) who observed that wh-movement languages do lack typing particles that are found in whin-situ languages, language internal and cross-linguistic data show that wh-questions (in addition to wh-word) have the same interrogative markers as yes/no questions. This makes it empirically possible for us to propose a unified analysis for both question types as well as dissociating movement of wh-phrase from clause typing. This being the case, the analysis assumed a common head structure for both yes/no question and whquestions thereby challenging the traditional analysis which claims that yes/no and whquestions involve different derivations.

\section{BIBLIOGRAPHIE}

Aboh, E. 2004. The Morpho syntax of complement-head sequence. Clause structure and word order. New York : Oxford University Press.

Aboh, E. 2007. Focused versus non-focused wh-phrases. Focus and grammar : The Contribution of African Languages. E. O. Aboh, H. Katharina, and Z. Malte. Eds. Moulton Berlin.

Aboh, E. 2010.Information structuring begins with the numeration. An International Journal of theoretical Linguistics $2.1: 12-42$.

Aboh, E. and Pfau, R. 2011. What's a wh-word Got to Do with it? The cartography of syntactic structures. B. Paola. Ed. New York : Oxford University Press. 5.

Cheng, L. 1991. On the typology of wh-questions. PhD. Thesis. MIT.

Chomsky, N. 1995. The Minimalist Program. MIT Press, Cambridge, Mass.

Chomsky, N. 1998. The Minimalist Inquiries : the Framework' in MIT Occasional Papers in Linguistics, No 15.

Chomsky, A. 2000. Minimalist inquires : The frame-work. step by step : Essays on Minimalist syntax in Honor of Howard Lasnik. D.Michaels and J. Uriagereka. Eds. Cambridge Mass. : MIT Press. 89-155.

Chomsky, N. 2002. On Nature and Language. Cambridge University Press, Cambridge. 
Collins, C. 2013. Introduction to Minimalist Syntax. African Linguistics School Handout, Ibadan, Nigeria.

Ilori, J.F. 2010. Nominal Constructions in Igala and Yoruba. PhD. Thesis. Dept. of Linguistics. Adekunle Ajasin University.

Ilori, J. F. 2017. Interrogative Projection in Yoruboid Languages. Journal of West African Languages 44.1.

Nkemnji, M. 1995. Heavy pied-piping in Nweh. PhD. Thesis. Dept. of Linguistics. University of California.

Olaogun, S.O. 2016. Information Structural Categories of the Ňjọ-Kóo Language in Akoko NorthWest of ondo state, Nigeria. PhD. Thesis. Dept. of Linguistics and African Languages. University of Ibadan.

Olaogun, S.O. 2017. On the So-called Interrogative Nouns in Yoruba. JOLAN : Journal of Linguistic Association of Nigeria.

Radford, A. 1988. Transformational grammar. Cambridge : Cambridge University Press.

Radford, A. 2009. An Introduction to English Sentence Structure. Cambridge : Cambridge University Press.

Rizzi, L. 1997. The fine structure of the left pheriphery. Element of grammar. Handbook of generative syntax. L. Heageman. Ed. Dordrecht : kluwer.

Uwalaka, M.A. 1991. Wh-movement in Igbo. UCL working papers in Linguistics $3: 186-208$.

Yimma, B. 1988. Focus in Oromo. Studies in African Linguistics $19: 365-384$.

Yusuf, O. 1992. Syntactic Analysis : A Student's Guide. Ilorin : Unilorin Press.

\section{NOTES}

1. Njọ̀-Kóo is the name proposed in Olaogun (2016) for a group of relatively mutually intelligible speech forms formally called Amgbé/Arigidi-Cluster spoken in the North-western part of Akoko in Ondo State, Nigeria. The language is spoken in at least six towns; Okèagbè, Igáșí, Àjọwá, Arigidi, and Erúșú made up of nine communities ; Igáșí, Arigidi, Erușú, Oyín, Urò in Àjowá, and Àfá, Ùdò, Ogè, Àjè in Okèàgbè all in Akoko North West Local Government in Ondo State. Njộ-Kóo is a compound name formed from $\mathbf{N}$ jọ̀ o and $\mathbf{N}$ Kó o (or N ghó o the variant of $\mathbf{N}$ kó o used in Urò) which is a form of greeting equivalent to Pẹlẹ́ o in Standard Yoruba.

2. For other appropriate responses, consider the following dialogue :

Speaker A : Uche, will you travel tomorrow

Speaker B : Yes/No

Speaker B is not under any obligation to answer yes/no to the question. S/he might choose to reply 'why do you ask?', 'I don't think so', 'maybe', 'How does that concern you ?', 'is not certain', and so forth.

3. It is observed that when 'konẹ' (who ?) is used in the language, two phonological processes are noticed, namely, deletion and assimilation. The /y/ in the question particle 'yè' is deleted while / è/ assimilates the preceding vowel of the question word.

4. This (EHT) Extra High tone is taken to be Emphatic head in this work assuming that questions and focus are generally emphasized. I therefore speculate that the high tone morpheme shows up whenever there is displacement of DP constituents within yes/no questions and focus constructions. 
The (EHT) is also used here to mean that the tone is absent in the declarative sentences from where the yes/no question clauses are formed. It does not refer to the pitch level of the high tone in the clause.

5. Úrá has two high tones in citation form but is correctly written as ura here because the language disallows a sequence of $\mathrm{HHH}$. When this happens, its phonological rule requires that the last two $\mathrm{HH}$ be lowered than the first.

\section{RÉSUMÉS}

Cet article, s'inscrit dans le cadre minimaliste de la syntaxe générative et étudie oui / non et whquestions dans la langue Ǹjọ̀-kóo (Benue-Congo), parlée dans l'état de Ondo au Nigeria. On observe que la particule interrogative pour des questions de type oui / non qui suit systématiquement le sujet DP se trouve également dans des clauses avec wh-questions. Cet article soutient que oui / non et wh-questions sont projetées par la même tête fonctionnelle Inter ${ }^{\circ}$, et que wh-words ne participent pas à la saisie de wh-propositions comme interrogative. L'article conclut que le mouvement de Wh-éléments vers la position initiale de la clause dans les langues à WH-mouvement n'a pas pour but l'interrogation mais plutôt pour la focalisation.

\section{INDEX}

Mots-clés : Propriété morphosyntaxique, Phrase complimenteur, Armature minimal, Njọ̀-kóo. Structure d'information évidence, Clause typing.

Keywords : Two main cross-linguistic claims are often made with regard to question formation in language, namely, that yes/no questions and wh-questions involve different syntactic derivations even though they may appear to have in common, some morphosyntactic properties such as the presence of a question particle, auxiliary insertion, or word order alternation, and that wh-questions are clause-typed by the movement of the wh-phrase to the Spec of complementizer phrase. This paper, adopting the minimalist framework of generative syntax, investigates yes/no and wh-questions in Ňjọ-kóo, and observes that the yes/no question particle that consistently follows the subject DP in yes/no question clause in the language is also found in wh-questions. This being the case, the paper argues that yes/no and wh-questions are projected by the same functional head Inter ${ }^{\circ}$, and that wh-words do not participate in typing wh-clauses as interrogative. The paper, leaning on clause typing and information structure evidence, concludes that the movement of wh-elements to the clause initial position in wh-movement languages is never for interrogation but rather for focus purposes.

\section{AUTEUR}

\section{SIMEON OLAOGUN}

Adekunle Ajasin University, Akungba-Akoko, Ondo State, Nigeria.

simeon.olaogun@aaua.edu.ng 